\title{
Why socio-economic and attitudinal factors cannot predict entomophagy in rural areas of Madagascar
}

\author{
A. Meysing ${ }^{*}$ iD, S. Forneck ${ }^{1}$, A. Razafindrakotomamonjy ${ }^{2}$ and J. Dürr ${ }^{1}$ \\ ${ }^{1}$ Center for Development Research (ZEF), University of Bonn, Genscherallee 3, 53113 Bonn, Germany; ${ }^{2}$ Laboratoire \\ d'entomologie DRA/FOFIFA, Ambatobe, BP 1 444, Antananarivo 101, Madagascar; anne.meysing@gmx.de
}

Received: 13 May 2021 / Accepted: 24 September 2021

(c) 2021 Wageningen Academic Publishers

OPEN ACCESS (c) (i) RESEARCH ARTICLE

\begin{abstract}
Entomophagy is commonly promoted as one solution to fight global food insecurity. Although many research articles have been published on the perception and acceptance of edible insects in Western nations, comparatively little attention has been paid to developing countries. To narrow down the existing research gap, this study investigates insect consumption behaviour in rural areas of Madagascar, a country that is severely affected by chronic malnutrition. The data was obtained from a household survey conducted in January 2020 in the rural commune of Sandrandahy in the central highlands of Madagascar. Using systematic cluster sampling with probability proportional to size, in 12 out of 38 villages, a sample of 216 households was randomly chosen. Multiple linear regressions were used to determine factors that explain differences in the quantities of insects consumed between local consumers. The amount of time households spent for insect harvesting, a variable which was not considered in any of the other studies reviewed, is the single most important factor explaining the amounts of insects consumed. In light of the results, we try to explain why socio-economic factors and most of the product-related attitudinal factors do not play a role in predicting insect consumption patterns in rural areas of Madagascar. More studies with larger samples in Madagascar and other sub-Saharan African countries are needed to validate the results. Future research should seek to make use of mixed-method approaches to provide more context-specific instruments. The promotion of insect rearing as a farming activity, as opposed to harvesting in the wild, is recommended to overcome seasonal availability gaps, exploit the tremendous potential of edible insects for food security, and strengthen the tradition of entomophagy.
\end{abstract}

Keywords: edible insects, food security, consumption patterns, household survey, multiple linear regression analysis

\section{Introduction}

Food security is one of the greatest challenges that societies face in the current century, with the COVID-19 pandemic making the situation even more precarious (FAO, IFAD, UNICEF, WFP, WHO, 2021; Global Panel on Agriculture and Food Systems for Nutrition, 2016; Van Huis et al., 2013). To meet the growing global nutritional demand, the result of a projected world population growth of over nine billion by 2050, agricultural production would need to be drastically expanded (UN, 2015). This growth is accompanied by an increase in the demand for livestock products (Thornton, 2010). On such a large scale, however, traditional livestock farming and meat production become increasingly unsustainable and alternative protein sources are needed. The growing pressure on land is particularly critical for low-income countries, which are already experiencing difficulties in meeting their nutritional needs (FAO, 2009). According to the United Nations Food and Agriculture Organization (FAO), about two billion people globally have experienced moderate to severe levels of food insecurity leading to chronic undernourishment, mainly due to protein deficiency and a lack of energy from food (FAO, IFAD, UNICEF, WFP, WHO, 2019). Among them, 'approximately 150 million children worldwide do not consume the required amounts of energy or nutrients for growth and development' (Tao and Li, 2018: 18), which, if untreated, may have life-threatening consequences. 
With $42 \%$ as of 2018 , Madagascar has one of the highest rates of chronic malnutrition worldwide (UN, 2021). One of the possible responses to malnutrition is the practice of eating insects, promoted by the FAO as an important pillar of the future food and feed security (Van Huis et al., 2013). Commonly referred to as entomophagy, it offers significant advantages over alternative protein sources: (1) a highly nutritional composition of proteins, fats, vitamins and minerals, (2) lower emissions of greenhouse gases and ammonia, (3) reduced use of water and land, (4) short life cycles and (5) a high feed conversion efficiency (i.e. conversion of feed mass into body mass) (Van Huis, 2013). Despite the fact that many poor countries are culturally rooted in entomophagy and that insects are abundant and play an essential role in rural communities (Gahukar, 2020), malnutrition predominates in these areas. In view of the 'SDGs aim to end all forms of hunger and malnutrition by 2030' (UN, 2020), there is an urgent need to investigate the insect consumption behaviour in a country like Madagascar, which is strongly affected by chronic malnutrition. Considering the above, the question arises: which factors favour or impede insect consumption? Greater understanding in this area could conceivably harness the potential of insects in combating malnutrition.

The benefits of insect consumption as sustainable protein sources have been conclusively shown in many studies, but, self-evidently, they can only be realised if people choose to eat insects in sufficient quantity (Van Huis, 2013). Understanding consumers' current perceptions of the use of insects as human food plays a key role in the future prospect and promotion of entomophagy (Mancini et al., 2019). To the authors' best knowledge, factors predicting insect consumption have been extensively studied in industrialised countries, but few studies on this topic were carried out in sub-Saharan Africa. Therefore, no research has examined predictors of acceptance and consumption of edible insects in Madagascar so far. Moreover, no clear data on insect collection practices nor consumption frequencies and quantities are available for Madagascar (Van Itterbeeck et al., 2019). In addition, the tendency of previous literature to only focus on the impact of isolated factors rather than their complex interplay has been criticised (Shepherd, 2005). Based on this criticism, the present analysis aims to consider several potential factors while comparing their explanatory power. Therefore, the paper aims to fill this gap in the literature by answering the following research question: which factors can be identified that explain differences in the quantity of insect consumption between Malagasy households? The objective of this analysis is twofold: (1) to gain a better understanding of insect consumption patterns among the rural population and (2) to examine the effect of socio-economic and productrelated attitudinal variables on Malagasy households' insect consumption behaviour.
The paper is divided into four parts, besides this introduction. In the following section, theoretical insight into factors that might influence edible insect consumption is given by presenting the theoretical framework and the empirical background. The subsequent section describes the methodological procedure, followed by the presentation of the results. Finally, the findings are integrated into the current state of research and critically discussed.

\section{Factors influencing insect consumption}

According to Shepherd's model (Shepherd and Raats, 1996), three classes of factors that influence food choice can be distinguished: (1) individual consumer characteristics; (2) factors related to the consumers' external environment; and (3) product-related factors. The first class comprises consumer characteristics of either a socio-demographic or a psychological nature ranging from age, gender or level of education to food neophobia, among others. The consumers' external environment, within which consumption decisions are made, includes religious and cultural beliefs and other social contexts. The third class of factors, product-related factors, concerns product properties (e.g. nutritional content) and anticipated consequences of ingestion (e.g. healthiness or food safety). All these factors are expected to influence food consumption patterns, defined as 'repeated arrangements that can be observed in the consumption of food by a population group' (Gerbens-Leenes and Nonhebel, 2005: 25). The three classes of factors described above are not independent of each other; instead, they are assumed to interact with each other (Shepherd and Raats, 1996).

In the literature on insect consumption, a number of factors fall within the three classes discussed as predictors of entomophagy. However, due to the almost total absence of such studies in Madagascar, those from other foodinsecure countries, in particular sub-Saharan African countries, predominantly form the empirical basis. The most important factors named in these studies are discussed below.

\section{Individual consumer characteristics}

Kisaka (2018) states that increased income correlates negatively with the consumption of winged termites in Kenyan households. As a possible explanation for this finding, the author posits that access to other protein sources such as meat is facilitated by increased income, which might lead to the perception of insects as food for the poor. Similar perceptions are also found in parts of Latin America (Costa-Neto, 2016). On the other hand, Manditsera et al. (2018) could only partially confirm this finding based on data obtained in Zimbabwe by highlighting that such an association is only valid for urban but not for rural areas. Regarding education, some studies argue that educated household decision-makers are more likely to 
accept insect consumption, presumably because of their greater knowledge about nutrition and the economic and ecological advantages (Kajale and Becker, 2015; Kisaka, 2018). In Zambia, though, no significant relationship between educational level and edible insect consumption can be found in rural areas, whereas the relationship is reported to be negative for urban households (Manditsera $e t$ al., 2018). In matters of age, an online study from Thailand and Mexico shows that younger people are more interested in purchasing insect-based products for consumption than older generations (Castro and Chambers, 2019). In contrast, studies on entomophagy in Ghana and Kenya have found a significantly higher likelihood of consumption in older age cohorts (Anankware et al., 2017; Kisaka, 2018). Finally, food neophobia, meaning 'the reluctance to eat, or the avoidance of new foods' (Nicklaus and Monnery-Patris, 2018: 262), can have a significantly negative effect on purchase intention and consumption of insects as shown, for example, in studies conducted in Taiwan and Kenya (Alemu et al., 2015; Chang et al., 2019).

\section{Household and external environmental factors}

As shown above, the individual factors predicting edible insect consumption often contradict each other, depending on where the studies were conducted. This might suggest that household-related and environmental factors play a role as well. Studies have shown that food preferences can vary widely even between neighbouring regions across the world; this variance almost certainly applies to Madagascar as well (Costa-Neto and Dunkel, 2016; Hanboonsong, 2010; Muafor et al., 2014; Randrianandrasana, 2014; Van Itterbeeck et al., 2019). Social context, meaning commonly shared perceptions and recommendations of members of the community, including but not limited to friends and family, can have a strong impact on decision-making (Alemu et al., 2015; Chang et al., 2019; Pambo et al., 2016a; Stull et al., 2018; Van Huis, 2013). Children tend to adopt the preferences of their parents (Ghosh et al., 2018; Tan et al., 2015), and their preferences vice versa can also influence the household's consumption (Liu et al., 2019; Pambo et al., 2016b). Regarding gender, most of the countries in which entomophagy is common, women and children are the primary gatherers of insects (Akullo et al., 2017; Ghosh et al., 2018; Kinyuru et al., 2018; Niassy et al., 2016; Van Huis et al., 2013; Yen, 2010). This holds true for previously studied sites of Madagascar as well (Van Itterbeeck et al., 2019). Because of their familiarity with harvesting, preparation and nutritional knowledge regarding insects, it could be assumed that this might encourage an increased insect consumption in female-headed households. In general, 'male- and female-headed households often behave differently relative to food consumption' (Ruel et al., 2005: 38). In addition, religious and cultural beliefs and taboos can play an important role regarding eating habits (Ebenebe et al., 2017; Ghosh et al., 2020; Obopile and Seeletso, 2013;
Tamesse et al., 2016; Van Huis, 2013). Due to different doctrines, some churches permit insect consumption (e.g. most traditional and Pentecostal churches), whereas in others it is strictly forbidden (e.g. apostolic churches) (Manditsera et al., 2018; Van Itterbeeck et al., 2019). Also, for example, in parts of Madagascar a cultural taboo exists that forbids the eating of mole crickets. It is said that their behaviour resembles the behaviour of a careless child, which is why they are presumably humanised by calling them 'lost children' and therefore spared from being eaten (Van Itterbeeck et al., 2019). Apart from that, particular types of insects might be considered sacred, polluted, or solely consumed in certain stages of development (Bergier, 1941; Silow, 1976). Lastly, some insect taboos only affect particular groups of people, for example, married, pregnant, men or women (Pagezy, 1975). Depending on the location, be it urban or rural, people consume varying amounts of insects. In settlements in the countryside, insect consumption tends to be significantly higher than in a city (Anankware et al., 2017; Gahukar, 2020; Manditsera et al., 2018) since edible insects are mostly found in rural areas and often collected in the wild. Harvesting of insects can be performed as a side activity, especially in the fields during agricultural work (Anankware et al., 2017; Chakravorty et al., 2013; Manditsera et al., 2018; Meyer-Rochow and Chakravorty, 2013; Van Huis et al., 2013). Adding to this, rural households often consist of more members, in particular children, who tend to harvest, and sometimes also consume, significantly more insects (Christensen et al., 2006; Kisaka, 2018; Liu et al., 2019; Pambo et al., 2016a,b; Van Itterbeeck et al., 2019).

\section{Product-related factors}

Another important factor discussed as a predictor for insect consumption is convenience. According to several studies, if the perceived convenience of a food product is high, including the ease of access and knowledge about gathering, processing and storage, then consumption by households is increased in urban as well as rural areas (Chakravorty et al., 2013, 2019; Okia et al., 2017; RamosElorduy, 2009; Tan et al., 2015; Van Huis et al., 2013). Regarding insects, this means that more common and easily harvestable species would usually be consumed more often. This has already been proven true for several study sites in Congo, Indonesia, Zimbabwe, Benin as well as Madagascar (Costa-Neto and Dunkel, 2016; Gahukar, 2016; Manditsera et al., 2018; Ramandey and Van Mastrigt, 2010; Randrianandrasana, 2014; Riggi et al., 2013). Few studies conducted in developing countries exist, which assess the impact of nutritional knowledge on food choice. Cox et al. (2020), Kekeunou et al. (2020), Manditsera et al. (2018), and Tamesse et al. (2018) reported nutritional value as being ranked very high in their surveys in Zimbabwe, Cameroon and Burkina Faso. In contrast, Akullo et al. (2017) and Obopile and Seeletso (2013) found a very low impact of knowledge on preferences during their fieldwork 
in Botswana and Uganda. Food safety aspects also play an important role when deciding whether or not to purchase or consume insects (Liu et al., 2019; Manditsera et al., 2018). Moreover, even if this is more often studied and confirmed for Western societies, Pambo et al. (2016b) also found that environmental responsibility is a main predictor of consumers' acceptance of edible insects in Western Kenya. Lastly, as illustrated by various scholars, perceived health benefits can constitute another important explanatory factor underlying food choice (Cox et al., 2020; Kapesa et al., 2020; Kisaka, 2018; Siegrist, 2008; Van Huis, 2013).

\section{Methodology}

\section{Study site and participants}

The current case study investigates the example of Sandrandahy, a town and commune in the central highlands of Madagascar (Figure S1). The commune resides between 1,200 to 1,500 meters above mean sea level, having a tropical climate with a hot and humid season between October and April and a cool, dry season between May and September (Office National de l'Environnement, 2007). The socioeconomic household survey was conducted within the 'ProciNut' (Production and Processing of Edible Insects for Improved Nutrition) project. This project aims at better exploiting the nutritional and economic potential of edible insects in Madagascar and Myanmar. The region had been chosen for different reasons. Besides accessibility and travel safety, we had realised that insect consumption is already part of the food habits in the villages of Sandrandahy and people were interested in insect production. Moreover, the region is characterised by high levels of poverty and food insecurity as well as low socio-economic potential. As the local diet consists mainly of staple crops (i.e. rice, cassava, sweet potato and maize), it tends to be unbalanced. Therefore it can be assumed that a rise in protein intake through increased insect consumption may be beneficial (Dürr et al., 2020).

Given our limited resources (feasibility) and also taking into account the difficulties to reach the villages, it was decided that interviews in 12 out of the 38 villages of the commune would be realistically manageable. We did not determine the sample size beforehand, but, given the time restriction, we realised that 18 interviews could be carried out in each village. The sample design used a multistage random procedure. First, the 12 of 38 villages within the commune Sandrandahy were selected using a systematicrandom sample of clusters with probability proportional to size to ensure that every household in all villages had the same probability of being drawn (according to Magnani, 1999). In each of the clusters/villages, households were then randomly selected from the respective household lists. The population covered by the survey amounts to 216 households or 1,185 individuals. In each household, preferably the head of household and/or the spouse were interviewed to ensure the respondents' familiarity with each household's consumption. The sample included $n=143$ male (66\%) and $n=73$ female (34\%) interviewees, of which $72 \%$ were heads of household.

Thanks to prior consultation with their respective village chiefs, the participation rate was extremely high. Only two households refused to participate in the study because of time constraints.

\section{Data collection}

Data collection took place in January 2020 by performing face-to-face interviews. Six local enumerators were recruited by the local cooperation partner of ProciNut, the National Center for Applied Research on Rural Development in Madagascar (FOFIFA), and trained on questioning techniques before conducting the survey. The questionnaire was pretested to assess its comprehensibility and cultural appropriateness and ensure the enumerators' uniform interviewing techniques. Beforehand, the enumerators were announced by the village chiefs to establish a basis of trust. Participation was voluntary; respondents did not receive any monetary compensation. The computer-assisted, personal interview survey software KoBoToolbox, which the Harvard Humanitarian Initiative developed for humanitarian contexts, was used for the data collection. The enumerators entered the interviewees' answers via smartphones into a data collection app, which guaranteed a standardised sequence of questions and the absence of missing values. In case a selected household was not available, the interview team returned the following day. If this attempt was also unsuccessful, another household was randomly chosen. The research project was approved by the head of the Amoron'i Mania region, the prefecture of Ambositra district, the mayor of Sandrandahy commune, and each village's chief.

\section{Questionnaire design and data analysis}

Based upon the literature review, the individual characteristics age, education and food neophobia ('If I don't know what is in the food, I won't try it') were chosen to be included in the analysis. For analytical reasons, we separated them from the socio-economic variables, i.e. income and food expenditures, in the regression models. Also, we do not know how income influences expenditures, according to Engels' law, nor how expenditures affect consumption of certain items such as insects, especially in subsistence-oriented agricultural households. Therefore, food expenditures were included as an additional variable that was not used in other studies. The household environment considered the variables household size, female vs male-headed, religion and rural vs urban site. The five main product-related factors found in the literature were each covered by one item in the questionnaire: nutritional value ('Have you heard prior to this survey that 
foods from edible insects can provide essential nutrients for humans?'), convenience ('Edible insects are easy to prepare'), food safety ('I have concerns about the cleanliness of edible insects'), health benefits ('When consumed, insects have positive health benefits for humans') and environmental aspects ('I am concerned about the environmental impact of my food choice').

Three response categories were given for each statement ('agree', 'disagree' and 'unsure'). Responses from the product-related attitudinal statements were transformed into a binary format by coding 'disagree' and 'unsure' as 0 and 'agree' as 1 . To counteract the tendency of respondents to agree with statements regardless of their actual attitude towards insects, also known as acquiescence bias, some items were reversely formulated (Tavakoli, 2012). Finally, we also considered two harvesting-related variables: (1) time spent on harvesting per month and (2) irrigated land size, where edible insects are commonly collected. The rationale behind this was that in rural areas insect consumption depends mainly on collection, which is affected positively by these two variables.

Food frequency tables were used to determine the consumption amounts of each insect species by asking how often (per day/week/month), for how many days/ weeks/months, and in what quantities households eat the respective species. Volumetric units (such as 'cups' or 'litres') were converted into mass ( $\mathrm{kg}$ ) by a standardised factor (e.g. one cup $=200 \mathrm{~g}$ ). Consumption amounts reflect the consumption of the whole household, not differentiating between individual household members. The dependent variable used, insect consumption (in $\mathrm{kg}$ ) per capita, is calculated by dividing the total household consumption of all insect species consumed $(\mathrm{kg})$ by the number of household members.

The questionnaire was developed in English, as this was the only common language of all researchers involved in the study and translated into Malagasy before implementation. Data analyses were carried out using IBM SPSS Statistics (version 27.0). Multiple linear regressions were calculated to determine the statistical significance of the relationship between the dependent variable (DV) and the various independent variables (IVs).

\section{Results}

\section{Descriptive statistics}

The vast majority of households (95\%) stated that they consume insects, most of them harvesting the insects in the wild (91\%). Conversely, the purchase of insects is relatively low (14\% of households). However, the amounts of insects consumed differed significantly depending on the species (Table 1). The most commonly consumed insect species among the interviewed households is Voangory [white grubs and African black beetle, Table S1], with an average yearly consumption of $5.92 \mathrm{~kg}(S D=7.33)$ per household. The Voangory are adult beetles belonging to the family of Melolonthinae and lead an underground life during the day and emerge and fly as soon as the sun sets. During this flight, adults are numerous and are found near rice fields or on land with grasses and shrubs where they can be easily caught. Other insect species consumed in descending order of quantity are Jorery [spittle bugs] $(M=0.92 \mathrm{~kg}, S D=2.50)$, Valala [locusts and grasshoppers] $(M=0.90 \mathrm{~kg}, S D=2.61)$, Abado [pupae of snout beetles, white grubs and African black beetle], Voanosy [snout beetles], Sakivy [larvae of snout beetles, white grubs and African black beetle], Zanadandy-Soherina [silkworm and wild silkworm], Tsikovoka [diving beetles] and Akitra [crickets]. Taking all species together, the average annual quantity of insects eaten by a household is $8.99 \mathrm{~kg}(S D=10.61)$, which corresponds to an average consumption of $1.71 \mathrm{~kg}$ $(S D=2.04)$ per capita per year.

When asked whether they would choose a free plate of insects or a free plate of meat, slightly over half (52\%) responded that they would choose the latter, $37 \%$ would prefer insects over meat and $11 \%$ stated no discernible preference. Almost three quarters of the households (74\%) would like to consume more insects and $81 \%$ reported a decline in harvested insect quantities. In line with this, most households (76\%) indicated that they would be interested in rearing insects. When asked why they eat insects (multiple answers possible), $88 \%$ of the interviewees stated that insects taste good and 65\% emphasised the role of insects as traditional food. In addition, $43 \%$ think that insects have a good texture, while $38 \%$ and $36 \%$ consider insects healthy and easily accessible food, respectively.

Table 1. Percentage of consuming households (hh) and household insect consumption in kg.

\begin{tabular}{|c|c|c|c|c|c|c|c|c|c|c|}
\hline & $\begin{array}{l}\text { Beetle (adult) } \\
\text { Voangory }\end{array}$ & $\begin{array}{l}\text { Cicada } \\
\text { Jorery }\end{array}$ & $\begin{array}{l}\text { Locust } \\
\text { Valala }\end{array}$ & $\begin{array}{l}\text { Beetle (pupae) } \\
\text { Abado }\end{array}$ & $\begin{array}{l}\text { Beetle (adult) } \\
\text { Voanosy }\end{array}$ & $\begin{array}{l}\text { Beetle (larva) } \\
\text { Sakivy }\end{array}$ & $\begin{array}{l}\text { Silkworm } \\
\text { Zanadandy }\end{array}$ & $\begin{array}{l}\text { Diving beetle } \\
\text { Tsikovoka }\end{array}$ & $\begin{array}{l}\text { Cricket } \\
\text { Akitra }\end{array}$ & Tota \\
\hline Consuming hh (\%) & 86.6 & 30.1 & 20.8 & 28.7 & 12.5 & 3.7 & 2.8 & 1.9 & 0.9 & 94.9 \\
\hline Consumption kg/hh & 5.9 & 0.9 & 0.9 & 0.5 & 0.5 & 0.2 & 0.0 & 0.0 & 0.0 & 9.0 \\
\hline $\mathrm{SD} \mathrm{kg} / \mathrm{hh}$ & 7.3 & 2.5 & 2.6 & 1.4 & 1.8 & 1.4 & 0.3 & 0.1 & 0.0 & 10.6 \\
\hline
\end{tabular}


Table 2 shows the proportions of the sample regarding education, religion, female-headed households, rural and urban population, the subjective statements towards edible insect consumption, and the respective means and standard deviations of average insect consumption per capita per subgroup. ANOVA and independent $t$-tests were used to find out significant differences between the group means.

The participants in this study largely have primary school education (56.5\%). Secondary schools, high schools and universities were attended by $24.5,12.0$ and $2.8 \%$, respectively, while $4.2 \%$ reported having no formal education. Those who had attained no formal education had the highest per capita insect consumption (1.92 kg), followed by primary school attendants $(1.83 \mathrm{~kg})$. However, ANOVA did not show significant differences between the groups ( $F=0.895 ; P=0.468)$. Regarding religious beliefs, $60.6 \%$ stated to be Catholic, 25.5\% Protestant, 11.6\% Lutheran and 2.3\%

\section{Table 2. Descriptive statistics of dummy variables used in the regression models, and mean and standard deviation values of insect consumption per capita in $\mathbf{k g} .{ }^{1}$}

\begin{tabular}{lrrrr} 
Variable & $\mathbf{n}$ & $\%$ & Mean & SD \\
& & & & \\
Total insect consumption per capita (kg) & 216 & 100.0 & 1.71 & 2.04 \\
Education & & & & \\
$\quad$ No school & 9 & 4.2 & 1.92 & 0.92 \\
Primary & 122 & 56.5 & 1.83 & 2.28 \\
Secondary & 53 & 24.5 & 1.77 & 1.98 \\
High school (Lycee) & 26 & 12.0 & 1.06 & 0.90 \\
$\quad$ University & 6 & 2.8 & 1.18 & 2.20 \\
Religion & & & & \\
$\quad$ Catholic & 131 & 60.6 & 1.86 & 2.07 \\
Protestant & 55 & 25.5 & 1.80 & 2.37 \\
Free church & 5 & 2.3 & 0.39 & 0.47 \\
$\quad$ Lutheran & 25 & 11.6 & 0.97 & 0.73 \\
Female-headed household & 22 & 10.2 & 1.52 & 1.87 \\
Male-headed household & 194 & 89.8 & 1.73 & 2.07 \\
Rural & 198 & 91.7 & 1.76 & 2.08 \\
Urban & 18 & 8.3 & 1.08 & 1.44 \\
Nutritional value: yes & 54 & 25.0 & 1.71 & 1.83 \\
Nutritional value: no & 162 & 75.0 & 1.71 & 2.11 \\
Convenience: yes & 210 & 97.2 & $1.75^{*}$ & 2.05 \\
Convenience: no & 6 & 2.8 & $0.08^{*}$ & 0.20 \\
Concern cleanliness: yes & 60 & 27.8 & 1.40 & 1.64 \\
Concern cleanliness: no & 156 & 72.2 & 1.83 & 2.17 \\
Food neophobia: yes & 54 & 25.0 & 1.26 & 1.61 \\
Food neophobia: no & 162 & 75.0 & 1.86 & 2.15 \\
Health benefits: yes & 154 & 71.3 & 1.83 & 1.77 \\
Health benefits: no & 62 & 28.7 & 1.40 & 2.60 \\
Environmental impact: yes & 139 & 64.4 & 1.90 & 2.17 \\
Environmental impact: no & 77 & 35.6 & 1.35 & 1.75 \\
\hline & & & & \\
\hline & & & \\
1 & & &
\end{tabular}

${ }^{1}$ An asterisk indicates significant differences at $P<0.05$. attend the free churches. Those attending free churches have a far lower per capita consumption $(0.39 \mathrm{~kg})$ than members of other churches $(0.97-1.86 \mathrm{~kg})$. Nevertheless, no significant group differences could be detected $(F=2.09$; $P=0.103)$.

There was no significant effect for female-headed households, which make up $10 \%$ of the sample, despite consuming $14 \%$ less than male-headed households, $t(214)=0.45, P=0.65$. Also, despite the insect consumption in Sandrandahy, the capital of the commune (i.e. a semi-urban area), being lower $(M=1.08, S D=1.44)$ than in the rural areas $(M=1.76$; $S D=2.08)$, no significant effect could be perceived, $t(214)=1.36$; $P=0.174$.

Regarding the subjective statements, the only significant differences exist between the $97 \%$ of respondents $(M=1.75$, $S D=2.05)$ who believe that insects are easy to prepare ('convenience'), and the remaining 3\% who hardly consume any insects $(M=0.08, S D=0.2)$. For all other variables, there are no significant group differences. $25 \%$ of respondents had heard that the consumption of edible insects can provide essential nutrients for humans. However, those being aware of the nutritional advantage consume the same amount as the remaining $75 \%$ of respondents, who had not heard about this fact. Nearly $28 \%$ of people are concerned about the food safety ('cleanliness') of edible insects; however, they and their family members still consume $1.40 \mathrm{~kg}$ per capita, not statistically different from the other group. One quarter of interviewees responded that if they did not know what was in the food, they would not try it ('food neophobia'). The insect consumption of this subgroup $(M=1.26 \mathrm{~kg})$ is lower than that of the comparison group $(M=1.86 \mathrm{~kg})$, but not significantly. $71 \%$ of respondents think that when consumed, insects have health benefits for humans. The consumption level of this subgroup $(1.83 \mathrm{~kg})$ is only slightly above the average. Finally, nearly two thirds are concerned about the environmental impact of their food choices. This subgroup consumes around half of a $\mathrm{kg}(550 \mathrm{~g})$ more insects than those who are not worried about the environmental impact, $t(214)=1.91 ; P=0.057$.

Respondents' ages ranged between 19 and 82, with a mean of 48 years (Table 3 ). The household size also varied considerably, ranging from 1 to $13(M=5.5, S D=2.2)$. The average annual cash income was 2.56 million Ariary per household (corresponding to $€ 648)^{1}$ or 536 thousand Ariary per capita $(€ 134)$. For food, households spent on average 86 thousand Ariary (€22) per capita per year. Regarding household possessions, on average, half of a hectare of irrigated land is owned per household. There is only one landless household in the sample, and the largest irrigated

\footnotetext{
${ }^{1}$ Exchange rate at the time of the study was approx. 1 Euro $=4,000$ Ariary.
} 
land size amounts to 3.3 hectares. Insects are collected one to two months per year and households harvest insects 34 hours per month on average during this time, with a maximum of 224 hours per month.

\section{Multiple linear regression models}

Following the theoretical tripartite division of factors described above, we tested and compared several multiple linear regression models with different compositions of the independent variable (Table 4) to explain differences in the dependent variable (per capita consumption). Based on the predictive power of the models and the characteristics of the IVs, the regression model with the highest fit was selected. This model was then examined and interpreted in more detail. Hence, for the first model, only socioeconomic variables have been included (Model 1). In a second step, these were extended by the factors belonging to individual consumer characteristics (Model 2). As a third step, factors related to the consumers' external environment

Table 3. Descriptive statistics of metric variables used in the regression models $(n=216)$.

$\begin{array}{lllll}\text { Variable } & \text { Min. } & \text { Max. } & \text { Mean } & \text { SD } \\ \text { Age } & 19 & 82 & 48.3 & 14.9 \\ \text { Number household members } & 1 & 13 & 5.5 & 2.2 \\ \text { Income per cap. (×1000 Ariary) } & 3 & 4,508 & 536 & 625 \\ \text { Food spending per cap. (×1000 Ariary) } & 9 & 589 & 86 & 80 \\ \text { Irrigated land (in ha) } & 0 & 3.33 & 0.49 & 0.45 \\ \text { Hours harvested/month } & 0 & 224 & 34 & 37\end{array}$

Table 4. Independent variables used in the regression models.

$\begin{array}{lll}\text { Model } & \text { Type of factors } & \text { Variables } \\ 1 & \text { Socioeconomic } & \text { Income per capita (×1000 Ariary) } \\ & & \text { Food expenditures (×1000 Ariary) } \\ 2 & \text { Individual } & \text { Age (years) } \\ & & \text { Education (dummy) } \\ & & \text { Food neophobia (dichot.) } \\ 3 & \text { Household/environment } & \text { Female-headed household (dichot.) } \\ & & \text { Religion (dummy) } \\ & & \text { Household size (number) } \\ & & \text { Rural/urban (dichot.) } \\ 4 & \text { Product-related } & \text { Nutrition (dichot.) } \\ & & \text { Convenience (dichot.) } \\ & & \text { Concern cleanliness (dichot.) } \\ & & \text { Health benefits (dichot.) } \\ & & \text { Environmental impact concerns } \\ & & \text { (dichot.) } \\ & & \text { Irrigated land size (acre) } \\ & & \text { Harvesting time (hours) }\end{array}$

(Model 3), and fourth, product-related factors (Model 4) were added and tested as independent models. In a final step, harvesting-related factors were incorporated as well (Model 5). Despite their absence of mention in literature, harvesting-related factors were included for exploratory purposes, because insect consumption in the study region is mainly based on gathering by consumers themselves, which requires time and access to land.

For the analysis, a hierarchical regression was run, which led to the results provided in Table 5.

Since the highest $\mathrm{R}^{2}$ value $(0.268)$ was achieved in Model 5 (Table 5), and since it is the only one of the five models that has become significant as an entire model, it was selected for further analysis. Excluding three influential cases (Cook's d), resulting in an $n=213$, we calculated the following results, which show that the selected model accounts for $28 \%$ of the variance in the DV (Table 6).

Because of heteroscedasticity problems (Breusch-Pagan test statistics: $\left.X^{2}=48.618 ; P=0.000\right)$ and non-normal distribution of residuals, we estimated the parameters using robust standard errors (HC4-method). Table 7 shows the results:

Only three variables show significant $P$-values: household size $(P=0.018)$, health benefits $(P=0.047)$ and harvesting time $(P=0.000)$. The influence of the household size on insect consumption is negative. In other words, each additional household member leads to an average consumption reduction of $144 \mathrm{~g}$ per capita. Nevertheless, the upper bound of the $95 \%$ confidence interval is only $-25 \mathrm{~g}$, so the effect size does not seem to be relevant (average consumption per capita for $\mathrm{n}=213$ is $1.58 \mathrm{~kg}$ ). In households that agreed that insect consumption brings health benefits, members are predicted to consume nearly half of a $\mathrm{kg}$ (481 g) more than those of other households. However, the $95 \%$ confidence interval ranges between 7 and 955 g; therefore, the effect might also be minimal. The significant coefficient $(P=0.00)$ of harvesting time is 0.019 , meaning that one hour of additional harvesting on average leads to an additional consumption of 19 g per capita ( $95 \%$ interval is between 10 and $29 \mathrm{~g}$ ).

The variable harvesting time shows the highest partial Etasquared $^{2}$. With 0.08 , it is much higher than that of health benefits (0.02) and household size (0.03). This means that it explains most of the regression results. For example, suppose we run a regression only including harvesting time as an independent variable. In that case, $R^{2}$ is still as high as 0.167 , whereas if we only run the regression with health and household size as independent variables, $\mathrm{R}^{2}$ is merely 0.05 .

\footnotetext{
${ }^{2}$ The partial Eta-squared describes the effect sizes of the different variables.
} 
A. Meysing et al.

Table 5. Multiple linear regression model summary; method: hierarchical regression.

$\begin{array}{lllllll}\text { Model } & \mathbf{R} & \mathbf{R}^{\mathbf{2}} & \text { Adjusted } \mathbf{R}^{2} & \text { Std. error of the estimate } & & \text { Significance } \\ 1 & & & & & & \\ 2 & 0.055 & 0.003 & -0.006 & 2.0502 & 0.324 & 0.724 \\ 3 & 0.231 & 0.053 & 0.017 & 2.0265 & 1.459 & 0.174 \\ 4 & 0.286 & 0.082 & 0.018 & 2.0255 & 1.278 & 0.224 \\ 5 & 0.339 & 0.115 & 0.029 & 2.0136 & 1.341 & 0.162 \\ & 0.518 & 0.268 & 0.189 & 1.8404 & 3.386 & 0.000\end{array}$

Table 6. Multiple linear regression model summary (Model 5); method: standard; 3 influential cases excluded ( $n=213$ ), dependent variable: insect consumption per capita in $\mathrm{kg}$.

\begin{tabular}{|c|c|c|c|c|c|c|c|}
\hline Model & $\mathbf{R}$ & $\mathbf{R}^{2}$ & Adjusted $\mathrm{R}^{2}$ & Std. error of the estimate & $\mathbf{F}$ & Sig. & Durbin-Watson \\
\hline 5 & 0.529 & 0.280 & 0.201 & 1.487 & 3.535 & 0.000 & 1.944 \\
\hline
\end{tabular}

Table 7. Multiple linear regression model coefficients with robust standard errors (Model 5). ${ }^{1}$

\begin{tabular}{|c|c|c|c|c|c|c|c|}
\hline \multirow[t]{2}{*}{ Parameter } & \multirow[t]{2}{*}{ Coefficient B } & \multirow[t]{2}{*}{ Robust std. error } & \multirow[t]{2}{*}{$\mathbf{T}$} & \multirow[t]{2}{*}{ Sig. } & \multicolumn{2}{|c|}{$95 \%$ confidence interval } & \multirow[t]{2}{*}{ Eta-squared } \\
\hline & & & & & Lower & Upper & \\
\hline Constant & 0.871 & 0.952 & 0.915 & 0.361 & -1.007 & 2.750 & 0.004 \\
\hline Income & 0.000 & 0.000 & 0.056 & 0.955 & 0.000 & 0.000 & 0.000 \\
\hline Food expend. & -0.001 & 0.002 & -0.670 & 0.504 & -0.005 & 0.003 & 0.002 \\
\hline Age & -0.007 & 0.007 & -0.966 & 0.335 & -0.020 & 0.007 & 0.005 \\
\hline Education_2 & -0.059 & 0.441 & -0.133 & 0.894 & -0.928 & 0.811 & 0.000 \\
\hline Education_3 & 0.212 & 0.521 & 0.407 & 0.685 & -0.815 & 1.239 & 0.001 \\
\hline Education_4 & -0.234 & 0.481 & -0.487 & 0.627 & -1.183 & 0.715 & 0.001 \\
\hline Education_5 & 0.335 & 0.812 & 0.412 & 0.681 & -1.267 & 1.936 & 0.001 \\
\hline Food neophobia & 0.116 & 0.259 & 0.450 & 0.653 & -0.394 & 0.627 & 0.001 \\
\hline Female household & 0.381 & 0.399 & 0.956 & 0.340 & -0.405 & 1.167 & 0.005 \\
\hline Religion_2 & 0.006 & 0.273 & 0.022 & 0.982 & -0.532 & 0.545 & 0.000 \\
\hline Religion_3 & -0.708 & 0.470 & -1.507 & 0.133 & -1.636 & 0.219 & 0.012 \\
\hline Religion_4 & -0.350 & 0.234 & -1.495 & 0.137 & -0.811 & 0.112 & 0.012 \\
\hline Household size & $-0.144^{*}$ & $0.060^{*}$ & $-2.385^{\star}$ & $0.018^{*}$ & $-0.264^{*}$ & $-0.025^{\star}$ & $0.029^{*}$ \\
\hline Rural urban & -0.152 & 0.386 & -0.395 & 0.694 & -0.913 & 0.608 & 0.001 \\
\hline Nutrition & -0.024 & 0.298 & -0.079 & 0.937 & -0.612 & 0.565 & 0.000 \\
\hline Convenience & 0.773 & 0.398 & 1.941 & 0.054 & -0.012 & 1.557 & 0.019 \\
\hline Cleanliness & -0.013 & 0.251 & -0.050 & 0.960 & -0.507 & 0.482 & 0.000 \\
\hline Health & $0.481^{*}$ & $0.240^{*}$ & $2.002^{*}$ & $0.047^{*}$ & $0.007^{*}$ & $0.955^{\star}$ & $0.021^{*}$ \\
\hline Environmental impact & 0.395 & 0.256 & 1.541 & 0.125 & -0.111 & 0.901 & 0.012 \\
\hline Irrigated land & -0.002 & 0.003 & -0.535 & 0.593 & -0.008 & 0.005 & 0.001 \\
\hline Harvest time & $0.019^{\star *}$ & $0.005^{\star *}$ & $4.117^{\star *}$ & $0.000^{* *}$ & $0.010^{* *}$ & $0.029^{* *}$ & $0.082^{* *}$ \\
\hline
\end{tabular}


Finally, to corroborate the results, a stepwise regression (inclusion criterion $P \leq 0.05$, exclusion criterion $P \geq 0.10$ ) was run with all variables to estimate the best-fit model. Table 8 and 9 show the results.

Again, the three significant variables from Model 5 (household size, health benefits and harvesting time) are included in Model 9, which additionally includes environmental concerns. The coefficients and significance levels are similar to those from Model 5. Likewise, the adjusted $R^{2}$ is comparable ( 0.226 vs 0.201$)$. In Model 9 , the variable' environmental concern' has a significant effect: people who agree that consuming insects is environmentally friendly, eat approximately half of a $\mathrm{kg}$ more insects on average. Nonetheless, as with health benefits, the $95 \%$ confidence level is relatively wide (it ranges from 39 to $884 \mathrm{~g}$ per capita). Furthermore, it is again harvesting time, which has the highest Eta-squared and best explains the regression results.

\section{Discussion}

We have seen that one single variable, harvesting time, explains most of the variances of the models applied. All of the other variables that have been included - socioeconomic, individual, external environment-related and product-related - cannot explain the dependent variable of per capita insect consumption to a satisfactory degree as expected (Models 1-4). Only when including harvesting time, the model becomes significant. However, its effect size is only low to moderate (adjusted $\mathrm{R}^{2}$ of 0.2 ). These unexpected findings raise three interrelated questions to be discussed: (1) why is a single variable so crucial in this case study?, (2) why do most of the other variables fail to explain insect consumption, in contradiction to previous research results?, and (3) which other factors explaining differences in Malagasy households' insect consumptions might exist?

Our data suggest a relatively simple answer to the first question: Most of the insects consumed are harvested and not purchased by the households and only few of the insects harvested are sold on the market afterwards. Therefore, it is not surprising that harvesting time directly influences the availability of insects for a household's consumption. However, we also registered relatively significant differences in the amounts of insects harvested per hour $(M=0.29 \mathrm{~kg}$, $S D=0.36 \mathrm{~kg}$ ). Therefore, besides time spent on harvesting, finding and collecting insects efficiently may play a crucial role in explaining deviations in consumption amounts. Even more so, insects are mainly collected by children: more than two thirds $(68 \%)$ of harvesting is done by the group between 5 and 15 years of age, which is in accordance with other studies (Costa-Neto and Dunkel, 2016; Ghosh et al., 2018; Kinyuru et al., 2018; Riggi et al., 2013; Stull et al., 2018; Van Itterbeeck et al., 2019). These children can easily pick up beetles such as the Voangory because of their slow, low-altitude flights and their tendency to remain on shrubs. The children catch them with their hands, then put them in a bucket or container with water to prevent

Table 8. Multiple linear regression model summary; method: stepwise regression.

\begin{tabular}{lllllll} 
Model & $\mathbf{R}$ & $\mathbf{R}^{2}$ & Adjusted $\mathbf{R}^{2}$ & Std. error of the estimate & $\mathbf{F}$ & Significance \\
6 & & & & & 42.179 & 0.000 \\
7 & 0.408 & 0.167 & 0.163 & 1.523 & 25.550 & 0.000 \\
8 & 0.442 & 0.196 & 0.188 & 1.500 & 20.089 & 0.000 \\
9 & 0.473 & 0.224 & 0.213 & 1.477 & 16.477 & 0.000 \\
\hline
\end{tabular}

${ }^{1}$ Variables included in Model 6: harvesting time; Model 7: harvesting time, household size; Model 8: harvest time, household size, health benefits; Model 9: harvesting time, household size, health benefits, environmental impact.

Table 9. Multiple linear regression model coefficients with robust standard errors (Model 9).

\begin{tabular}{lccccccc} 
Parameter & Coefficient B & Robust std. error & T & Significance & \multicolumn{2}{c}{$95 \%$ confidence interval Eta squared } \\
& & & & & Lower & Upper \\
Constant & 0.972 & 0.306 & 3.171 & 0.002 & 0.367 & 1.576 & 0.046 \\
Harvest time & 0.021 & 0.005 & 4.170 & 0.000 & 0.011 & 0.031 & 0.077 \\
Household size & -0.138 & 0.055 & -2.535 & 0.012 & -0.246 & -0.031 & 0.030 \\
Health & 0.526 & 0.219 & 2.401 & 0.017 & 0.094 & 0.957 & 0.027 \\
Environmental impact & 0.461 & 0.214 & 2.152 & 0.033 & 0.039 & 0.884 & 0.022
\end{tabular}


escape during collection. However, children might have very different levels of motivation and experience, especially when considering the age range (5-15). If children are the primary collectors, their willingness and capacity to harvest insects might be an important explanatory variable not investigated in this research. One may also assume that the more children live in a household, the more cumulative time is spent on harvesting resulting in higher amounts harvested. This is actually the case in our sample, but a higher number of children means not only more gatherers but also more consumers, countervailing the effect on per capita consumption. In fact, we have seen that a bigger household size leads to lower per capita consumption.

In contradiction to the empirical literature, most other factors were not well suited to explain insect consumption quantities in our sample. Given this unexpected finding, the question arises as to why the present results differ from those found in other sub-Saharan countries. One explanation could be that our study calculates consumption amounts and relates these to the explanatory variables using regression analysis. It might be the case that the factors found in the literature have a different impact when trying to explain quantities (and not motivations to consume, for example). However, in the only study we found which uses a double-hurdle regression model to explain quantities of edible winged termites in Kenya (Kisaka, 2018), socio-economic and product-related attributes are significant predictors. Nevertheless, it is unclear if the consumed termites come from wild harvesting or are bought on the market. If, as in our study area, wild collection is predominant, explanatory factors might be different. Secondly, most sub-Saharan countries mentioned in the literature have, in contrast to Madagascar, a significantly higher GDP per capita (Worldbank, 2019). This suggests that there are more decision-making options in those countries when it comes to food selection. Thus, factors other than mere satiety may play a role in these cases. Another aspect that should be considered is that Madagascar is unique due to its Indo-Malaysian heritage. Therefore, it sometimes has preferences very different from those commonly found in sub-Saharan Africa (Randrianandrasana, 2014). According to Randrianandrasana and Berenbaum (2015), Coleoptera are the most consumed insects in five different research sites in Madagascar, which agrees significantly more with Indo-Malayan preferences than sub-Saharan African ones. In Sandrandahy as well, Coleoptera are the main edible insects, consumed sometimes as nymphs [Abado] but mainly as imagos [Voangory]. Collecting or capturing Voangory has long been a traditional practice.

Accordingly, for the Sandrandahy sample, we could not show, as we had expected that the amount of edible insect consumption is significantly affected by income, age, education, religion, sex of head of household, rurality, food expenditures, irrigated land size, food neophobia, or most of the product-related preferences. This suggests that almost all households eat insects in a comparable quantity due to the widespread poverty and the overriding goal of satiating hunger. Alternatively, it might indicate that entomophagy is so deeply rooted in the Malagasy tradition that everybody eats insects no matter how rich or poor, educated or uneducated. The first explanation is consistent with Ramaroson Rakotosamimanana et al. (2015), finding that satiating hunger is one of the most important factors in food decisions among Malagasy low-income consumers. This corresponds to the fact that $92 \%$ of households that collect insects stated that the main reason for harvesting insects is that they can be consumed as a main dish with rice. This suggests that for people in Sandrandahy, insects constitute a welcome additional source of food and a meat substitute. In these poor rural areas, where protein-rich food is scarce, nearly everybody eats insects to complement the staple food-based diets.

Furthermore, insects are a traditional food (Randrianandrasana and Berenbaum, 2015; Van Itterbeeck et al., 2019) which most locals find delicious and easy to collect. As it is mainly children who harvest insects in the wild, the opportunity costs are low, and farmers take advantage of this nearly freely available resource. This could explain why in such an environment, other variables related to individual and household characteristics, or productrelated preferences, do not play a significant role in insect consumption. In short, we interpret our results as a consequence of the existing highly food-insecure, impoverished rural communities.

One more aspect merits consideration: as we have seen, most households stated that they would like to harvest more insects. However, a declining trend of harvested quantities has been reported by many respondents. This does not exclusively relate to the fact that insects are only seasonally available, but also that their occurrence seems to have been reduced in the last decades. In this context, overexploitation, as well as a loss of habitats due to the intensification of agriculture (e.g. intensive crop production/fertiliser/pesticides) or deforestation, needs to be considered (Boulidam, 2010; Dev et al., 2020; Dube et al., 2013; Meyer-Rochow and Chakravorty, 2013; Van Huis et al., 2013; Yen, 2010). Furthermore, when availability is a major constraint, the fact that some household members, especially the children, have better harvesting skills might be even more important to explain the differences in harvesting and hence, consumption amounts. These skills can include, for example, knowledge on where to find insects or how to collect them efficiently.

Finally, when discussing results, one has to acknowledge the limitations of our study. Besides the relatively small sample size used for multiple linear regression, a strong regional 
focus was chosen. Therefore, results cannot be generalised to other regions of Madagascar, let alone to other countries. Furthermore, Madagascar is a multi-ethnic country, and there may be noticeable differences in insect consumption patterns between different, sometimes even neighbouring, communities (Randrianandrasana and Berenbaum, 2015). In part, this is because 'the respective importance of factors underlying food choice [...] depends on the environment and the population or demographic group' (Ramaroson Rakotosamimanana et al., 2015: 534). The assumption that factors influencing insect consumption are the same, independently of the insect species, is another limitation of this study. On a theoretical basis, it is conceivable that factors might differ from species to species. However, the calculation of individual regressions per insect species was not pursued further due to the strong dominance of one single species in the sample.

Additionally, an interpretation of the results might be complicated because stated consumption may differ from actual consumption. Exact quantification of the households' edible insect consumption might be difficult due to the common recall bias (Barennes et al., 2015). This bias may occur in particular when the consumption amounts are queried over such a long time, in this case over the course of a year. To crosscheck, we compared the quantities of insects harvested with those consumed, but only few households (around 5\%) harvested much more, meaning more than the average consumption amount, than they consumed, or vice versa. One explanation could be that the harvested insects are gifted to or received from friends or neighbours. Another possible explanation is that harvesting is done mainly by children. Therefore, it is difficult for the interviewees to have a detailed overview of how much the children collected. It is also conceivable that the methodological decisions taken in this study have influenced the results, especially the calculation of the dependent variable. Since the amounts of insects consumed were only surveyed per household, per capita consumption was calculated as a simple division of each household's consumption divided by the respective number of household members.

Consequently, no precise statements can be made about individual consumption patterns. This does not appear to be a major limitation of data quality. However, relating the personal attitudes (i.e. attitudinal variables) of heads of household or their spouses to total household consumption is problematic because it is based on the assumption that the attitudes of heads of households towards insects are similar to those of other family members. Last but not least, two limitations have to be acknowledged regarding the general construction of the survey. Firstly, all five product-related attitudinal variables have been solely covered with one question each, which may have resulted in the constructs not being fully captured. Secondly, the response format was simplified to only three answer categories instead of using complex Likert-scales, which might have reflected consumer behaviour in a more differentiated way.

\section{Conclusions}

The literature review shows that the empirical evidence on factors predicting entomophagy in developing countries is still very inconsistent. In contrast to other studies, the present study only identified the variables household size, perceived health benefits, environmental concerns, and harvesting time as significant predictors of insect consumption. Harvesting time, not included in any other study reviewed, is the single most important factor explaining insect consumption amounts. However, what all studies, including this work, have consistently shown is the great interest in eating insects and that low levels of consumption can at least be partly attributed to their seasonality and overexploitation, a finding that is independent of all factors examined. More studies with larger samples in Madagascar and other sub-Saharan African countries are needed to validate the results. Future research should seek to use mixed-method approaches to provide more context-specific instruments, e.g. the combination of focus group discussions and quantitative surveys. More crucially, however, is the promotion of insect rearing as a farming activity, as opposed to wild harvesting, to overcome seasonal availability gaps, to exploit the tremendous potential of edible insects for food security, as well as for employment and income generation, and strengthen the tradition of entomophagy.

\section{Supplementary material}

Supplementary material can be found online at https://doi. org/10.3920/JIFF2021.0086.

Table S1. Main edible insects found in the area of Sandrandahy.

Figure S1. Map of the location of the Commune Sandrandahy within the region Amoron'i Mania and the region within Madagascar.

\section{Acknowledgements}

The authors gratefully acknowledge the assistance of the Madagascar ProciNut team members (Hery Andriamazaoro, Narilala Randrianarison, Christian Ratompoarison, Harifetra Andrianintsoa), who organised the field study very well under difficult conditions. Without their commitment, this study would not have been possible. We are also very grateful to the enumerators Saholiniaina Rasoanaivo, Irené Ratojonirainy, Yves Ralison, Tsiory Rakotobe, José Rasolofonirina, and Zo Randrianirisoa, 
who worked very hard and thoroughly carried out as many interviews as possible in the limited time available. The authors further thank the households, which participated in the survey, for their patience and time. Finally, we would like to express our sincere gratitude to Guido Lüchters for his constant willingness to help in statistical analysis and to Frank Borge Wietzke from the Institut Barcelona d' Estudis Internacionals for the continuous support of this research, his expertise and enthusiasm. This article has been written within the ProciNut project at Center for Development Research, University of Bonn, Germany. ProciNut is financially supported by the German Federal Ministry of Food and Agriculture (BMEL) based on the decision of the Parliament of the Federal Republic of Germany through the Federal Office for Agriculture and Food (BLE).

\section{Conflict of interest}

The authors declare that they have no conflict of interest.

\section{References}

Akullo, J., Obaa, B.B., Acai, J.O., Nakimbugwe, D. and Agea, J.G., 2017. Knowledge, attitudes and practices on edible insects in Lango subregion, northern Uganda. Journal of Insects as Food and Feed 3: 73-81. https://doi.org/10.3920/JIFF2016.0033

Alemu, M.H., Olsen, S.B., Vedel, S.E., Pambo, K.O. and Owine, V.O., 2015. Consumer acceptance and willingness to pay for edible insects as food in Kenya: the case of white winged termites. University of Copenhagen, Frederiksberg, Denmark, 27 pp.

Anankware, P.J., Osekre, E.A., Obeng-Ofori, D. and Khamala, C.M., 2017. Factors that affect entomophagical practices in Ghana. Journal of Insects as Food and Feed 3: 33-41. https://doi.org/10.3920/ JIFF2016.0007

Barennes, H., Phimmasane, M. and Rajaonarivo, C., 2015. Insect consumption to address undernutrition, a national survey on the prevalence of insect consumption among adults and vendors in Laos. PLoS ONE 10(8): e0136458. https://doi.org/10.1371/journal. pone. 0136458

Bergier, E., 1941. Peuples entomophages et insectes comestibles. Rullière Frères, Avignon, France.

Boulidam, S., 2010. Edible insects in a Lao market economy. In: Durst, P.B. (ed.) Forest insects as food: humans bite back. Proceedings of a workshop on Asia-Pacific resources and their potential for development. 19-21 February 2008. Chiang Mai, Thailand.

Castro, M. and Chambers, E., 2019. Willingness to eat an insect based product and impact on brand equity: a global perspective. Journal of Sensory Studies 34: e12486. https://doi.org/10.1111/joss.12486

Chakravorty, J., Ghosh, S. and Meyer-Rochow, V.B., 2013. Comparative survey of entomophagy and entomotherapeutic: practices in six tribes of eastern Arunachal Pradesh (India). Journal of Ethnobiology and Ethnomedicine 9: 50. https://doi.org/10.1186/1746-4269-9-50

Chakravorty, J., Jugli, S., Boria, M. and Meyer-Rochow, V.B., 2019. Arunachal's Adi and Apatani tribes' traditional knowledge of harvesting and using edible insects. Journal of Insects as Food and Feed 5: 125-135. https://doi.org/10.3920/JIFF2018.0019
Chang, H.-P., Ma, C.-C. and Chen, H.-S., 2019. Climate change and consumer's attitude toward insect food. International Journal of Environmental Research and Public Health 16: 1606. https://doi. org/10.3390/ijerph16091606

Christensen, D.L., Orech, F.O., Mungai, M.N., Larsen, T., Friis, H. and Aagaard-Hansen, J., 2006. Entomophagy among the Luo of Kenya: a potential mineral source? International Journal of Food Sciences and Nutrition 57: 198-203. https://doi.org/10.1080/09637480600738252

Costa-Neto, E.M., 2016. Edible insects in Latin America: old challenges, new opportunities. Journal of Insects as Food and Feed 2: 1-2. https://doi.org/10.3920/JIFF2016.x001

Costa-Neto, E.M. and Dunkel, F.V., 2016. Insect as food: history, culture and modern use around the world. In: Dossey, A.T., Morales-Ramos, J.A. and Rojas, M.G. (eds.) Insects as sustainable food ingredients: production, processing and food applications. Elsevier, New York, NY, USA.

Cox, S., Payne, C., Badolo, A., Attenborough, R. and Milbank, C., 2020. The nutritional role of insects as food: a case study of 'chitoumou' (Cirina butyrospermi), an edible caterpillar in rural Burkina Faso. Journal of Insects as Food and Feed 6: 69-80. https://doi.org/10.3920/ JIFF2018.0030

Dev, S., Hassan, K., Claes, J., Mozahid, M.N., Khatun, H. and Mondal, M.F., 2020. Practices of entomophagy and entomotherapy in Bangladesh. Journal of Insects as Food and Feed 6: 515-524. https:// doi.org/10.3920/JIFF2020.0038

Dube, S., Dlamini, N.R., Mafunga, A., Mukai, M. and Dhlamini, Z., 2013. A survey on entomophagy prevalence in Zimbabwe. African Journal of Food, Agriculture, Nutrition and Development 13: 72427253.

Dürr, J., Andriamazaoro, H., Nischalke, S., Preteseille, N., Rabenjanahary, A., Randrianarison, N., Ratompoarison, C., Razafindrakotomamonjy, A., Straub, P. and Wagler, I., 2020. 'It is edible, so we eat it': insect supply and consumption in the central highlands of Madagascar. International Journal of Tropical Insect Science 40: 167-179. https://doi.org/10.1007/s42690-019-00067-w Ebenebe, C.I., Amobi, M.I., Udegbala, C., Ufele, A.N. and Nweze, B.O., 2017. Survey of edible insect consumption in south-eastern Nigeria. Journal of Insects as Food and Feed 3: 241-252. https:// doi.org/10.3920/JIFF2017.0002

Food and Agriculture Organization of the United Nations (FAO), 2009. How to feed the world in 2050. FAO, Rome, Italy. Available at: http://www.fao.org/wsfs/forum2050/wsfs-forum/en/

Food and Agriculture Organization of the United Nations, International Fund for Agricultural Development, United Nations Children's Fund, World Food Programme and World Health Organization (FAO, IFAD, UNICEF, WFP, WHO), 2019. The State of food security and nutrition in the world 2019: safeguarding against economic slowdowns and downturns. FAO, Rome, Italy, $239 \mathrm{pp}$.

Food and Agriculture Organization of the United Nations, International Fund for Agricultural Development, United Nations Children's Fund, World Food Programme and World Health Organization (FAO, IFAD, UNICEF, WFP, WHO), 2021. The state of food security and nutrition in the world 2021. FAO, Rome, Italy, 240 pp. https://doi. org/10.4060/cb4474en 
Gahukar, R. T., 2016. Edible insects farming: efficiency and impact on family livelihood, food security, and environment compared with livestock and crops. In: Dossey, A.T., Morales-Ramos, J.A. and Rojas, M.G. (eds.) Insects as sustainable food ingredients: production, processing and food applications. Elsevier, New York, NY, USA.

Gahukar, R.T., 2020. Edible insects collected from forests for family livelihood and wellness of rural communities: a review. Global Food Security 25: 100348. https://doi.org/10.1016/j.gfs.2020.100348

Gerbens-Leenes, W. and Nonhebel, S., 2005. Food and land use. The influence of consumption patterns on the use of agricultural resources. Appetite 45: 24-31. https://doi.org/10.1016/j. appet.2005.01.011

Ghosh, S., Jung, C. and Meyer-Rochow, V.B., 2018. What governs selection and acceptance of edible insect species? In: Halloran, A., Flore, R., Vantomme, P. and Roos, N. (eds.) Edible insects in sustainable food systems. Springer, Cham, Switzerland.

Ghosh, S., Jung, C., Meyer-Rochow, V.B. and Dekebo, A., 2020. Perception of entomophagy by residents of Korea and Ethiopia revealed through structured questionnaire. Journal of Insects as Food and Feed 6: 59-64. https://doi.org/10.3920/JIFF2019.0013

Global Panel on Agriculture and Food Systems for Nutrition, 2016. Food systems and diets: facing the challenges of the $21^{\text {st }}$ century. lobal Panel on Agriculture and Food Systems for Nutrition, London, UK, 133 pp.

Hanboonsong, Y., 2010. Edible insects and associated food habits in Thailand. In: Durst, P.B. (ed.) Forest insects as food: humans bite back. Proceedings of a workshop on Asia-Pacific resources and their potential for development. 19-21 February 2008. Chiang Mai, Thailand.

Kajale, D.B. and Becker, T.C., 2015. Factors influencing young consumers' acceptance of genetically modified food in India. Journal of Food Products Marketing 21: 461-481. https://doi.org/10.1080 /10454446.2013.845866

Kapesa, K., Devi, W.D., Bonysana, R.K. and Rajashekar, Y., 2020. Anthropo-entomophagy and ethno-entomology among the ethnic Mao-Naga and Poumai-Naga tribes of Manipur, Northeast India. Journal of Insects as Food and Feed 6: 507-514. https://doi. org/10.3920/JIFF2020.0012

Kekeunou, S., Laïda, P.S., Achu-Loh, M.B., Tchouamou, C.D., SimoGuiadem, L., Pieme, C.A., Ngameni, B. and Tamesse, J.L., 2020. Ethnic heterogeneity of knowledge on Zonocerus variegatus and reasons for consumption and non-consumption in the southern part of Cameroon. Journal of Insects as Food and Feed 6: 273-283. https://doi.org/10.3920/JIFF2019.0035

Kinyuru, J.N., Nyangena, D., Kamau, E. and Ndiritu, A., 2018. The role of edible insects in diets and nutrition in East Africa. In: Halloran, A., Flore, R., Vantomme, P. and Roos, N. (eds.) Edible insects in sustainable food systems. Springer, Cham, Switzerland.

Kisaka, C., 2018. Evaluation of consumers acceptance and pricing of edible winged termites (Macrotermes subhylanus) in Kimilili SubCounty, Kenya. MSc-thesis, Egerton University, Njoro, Kenya, 96 pp.

Liu, A.-J., Li, J. and Gómez, M.I., 2019. Factors influencing consumption of edible insects for Chinese consumers. Insects 11: 10. https://doi. org/10.3390/insects11010010

Magnani, R., 1999. Sampling guide. FHI 360/FANTA, Washington, DC, USA.
Mancini, S., Sogari, G., Menozzi, D., Nuvoloni, R., Torracca, B., Moruzzo, R. and Paci, G., 2019. Factors predicting the intention of eating an insect-based product. Foods 8: 270. https://doi. org $/ 10.3390 /$ foods 8070270

Manditsera, F.A., Lakemond, C.M.M., Fogliano, V., Zvidzai, C.J. and Luning, P.A., 2018. Consumption patterns of edible insects in rural and urban areas of Zimbabwe: taste, nutritional value and availability are key elements for keeping the insect eating habit. Food Security 10: 561-570. https://doi.org/10.1007/s12571-018-0801-8

Meyer-Rochow, V.B. and Chakravorty, J., 2013. Notes on entomophagy and entomotherapy generally and information on the situation in India in particular. Applied Entomology and Zoology 48: 105-112. https://doi.org/10.1007/s13355-013-0171-9

Muafor, F.J., Levang, P. and Le Gall, P., 2014. A crispy delicacy: Augosoma beetle as alternative source of protein in East Cameroon. International Journal of Biodiversity, Article ID 214071. https://doi. org/10.1155/2014/214071

Niassy, S., Affognon, H.D., Fiaboe, K., Akutse, K.S., Tanga, C.M. and Ekesi, S., 2016. Some key elements on entomophagy in Africa: culture, gender and belief. Journal of Insects as Food and Feed 2: 139-144. https://doi.org/10.3920/JIFF2015.0084

Nicklaus, S. and Monnery-Patris, S., 2018. Food neophobia in children and its relationships with parental feeding practices/style. In: Reilly, S. (ed.) Food neophobia: behavioral and biological influences. Woodhead Publishing, Oxford, UK.

Obopile, M. and Seeletso, T.G., 2013. Eat or not eat: an analysis of the status of entomophagy in Botswana. Food Security 5: 817-824. https://doi.org/10.1007/s12571-013-0310-8

Office National de l'Environnement, 2007. Tableau de bord environnemental - Région Amorin'i Mania. Office National de l'Environnement, Antananarivo, Madagaskar.

Okia, C.A., Odongo, W., Nzabamwita, P., Ndimubandi, J., Nalika, N. and Nyeko, P., 2017. Local knowledge and practices on use and management of edible insects in Lake Victoria basin, East Africa. Journal of Insects as Food and Feed 3: 83-93. https://doi. org/10.3920/JIFF2016.0051

Pagezy, H., 1975. Les interrelations homme faune de la foret du Zaire. In: Pujol, R. (ed.) l'Homme et l'animal: premier colloque d'ethnozoologie. Institut International d'Ethnosciences, Paris, France.

Pambo, K., Mbeche, R.M., Okello, J.J., Kinyuru, J.N. and Mose, G.N., 2016a. Consumers' salient beliefs regarding foods from edible insects in Kenya: a qualitative study using concepts from the theory of planned behaviour. African Journal of Food, Agriculture, Nutrition and Development 16: 11366-11385. https://doi.org/10.18697/ ajfand.76.16810

Pambo, K.O., Okello, J.J., Mbeche, R.M. and Kinyuru, J.N., 2016b. Consumer acceptance of edible insects for non-meat protein in Western Kenya. Paper Prepared for presentation at the $5^{\text {th }}$ African Association of Agricultural Economists (AAAE) Conference. Addis Ababa, Ethiopia, 20 pp. https://doi.org/10.22004/ag.econ.246317

Ramandey, E. and Van Mastrigt, H., 2010. Edible insects in Papua, Indonesia: from delicious snack to basic need. In: Durst, P.B. (ed.) Forest insects as food: humans bite back. Proceedings of a workshop on Asia-Pacific resources and their potential for development. 19-21 February 2008. Chiang Mai, Thailand. 
Ramaroson Rakotosamimanana, V., Valentin, D. and Arvisenet, G., 2015. How to use local resources to fight malnutrition in Madagascar? A study combining a survey and a consumer test. Appetite 95: 533-543. https://doi.org/10.1016/j.appet.2015.08.011

Ramos-Elorduy, J., 2009. Anthropo-entomophagy: cultures, evolution and sustainability. Entomological Research 39: 271-288. https://doi. org/10.1111/j.1748-5967.2009.00238.x

Randrianandrasana, M., 2014. Antherina suraka (Lepidoptera: Saturniidae): ecology, systematics, and potential economic uses to promote conservation in Madagascar. Doctoral thesis, University of Illinois, Urbana, IL, USA, 180 pp.

Randrianandrasana, M. and Berenbaum, M. R., 2015. Edible noncrustacean arthropods in rural communities of Madagascar. Journal of Ethnobiology 35: 354-383. https://doi.org/10.2993/etbi-35-02354-383.1

Riggi, L.G., Veronesi, M., Verspoor, R. and MacFarlane, C., 2013. Exploring entomophagy in Northern Benin - practices, perceptions and possibilities. Bugs for life, London, UK, 40 pp. Available at: https://de.scribd.com/doc/144300137/Exploring-Entomophagyin-Northen-Benin-Practices-perceptions-and-possibilities

Ruel, M.T., Minot, N. and Smith, L., 2005. Patterns and determinants of fruit and vegetable consumption in sub-Saharan Africa: a multicountry comparison. WHO, Geneva, Switzerland.

Shepherd, R., 2005. Influences on food choice and dietary behavior. Forum of Nutrition 57: 36-43. https://doi.org/10.1159/000083752

Shepherd, R. and Raats, M., 1996. Attitudes and beliefs in food habits. In: Meiselman, H.L. and MacFie, H. (eds.) Food choice, acceptance and consumption. Springer, Boston, MA, USA.

Siegrist, M., 2008. Factors influencing public acceptance of innovative food technologies and products. Trends in Food Science \& Technology 19: 603-608. https://doi.org/10.1016/j.tifs.2008.01.017

Silow, C.A., 1976. Edible and other insects of mid-Western Zambia: studies in ethno-entomology II. Almqvist \& Wiksell, Upsalla, Sweden.

Stull, V.J., Wamulume, M., Mwalukanga, M.I., Banda, A., Bergmans, R.S. and Bell, M.M., 2018. 'We like insects here': entomophagy and society in a Zambian village. Agriculture and Human Values 35: 867-883. https://doi.org/10.1007/s10460-018-9878-0

Tamesse, J.L., Kekeunou, S., Tchatchouang, L.J., Ndegue, O., Aissatou, L.M., Tombouck, D. and Youssa, B., 2016. Insects as food, traditional medicine and cultural rites in the west and south regions of Cameroon. Journal of Insects as Food and Feed 2: 153-160. https:// doi.org/10.3920/JIFF2015.0088

Tamesse, J.L., Kekeunou, S., Tchouamou, C.D. and Meupia, M.J., 2018. Villagers' knowledge of some edible insects in southern Cameroon: crickets, termites, honeybees and cockchafers. Journal of Insects as Food and Feed 4: 203-209. https://doi.org/10.3920/JIFF2017.0077
Tan, H.S.G., Fischer, A.R., Tinchan, P., Stieger, M., Steenbekkers, L. and Van Trijp, H.C., 2015. Insects as food: exploring cultural exposure and individual experience as determinants of acceptance. Food Quality and Preference 42: 78-89. https://doi.org/10.1016/j. foodqual.2015.01.013

Tao, J. and Li, Y.O., 2018. Edible insects as a means to address global malnutrition and food insecurity issues. Food Quality and Safety 2: 17-26. https://doi.org/10.1093/fqsafe/fyy001

Tavakoli, H., 2012. A dictionary of research methodology and statistics in applied linguistics. Rahnamā, Tehran, Iran, 753 pp.

Thornton, P.K., 2010. Livestock production: recent trends, future prospects. Philosophical Transactions of the Royal Society of London. Series B, Biological Sciences 365: 2853-2867. https://doi. org/10.1098/rstb.2010.0134

United Nations (UN), 2015. World population prospects: the 2015 revision, key findings and advance tables. UN, New York, NY, USA. Available at: https://population.un.org/wpp/Publications/Files/ Key_Findings_WPP_2015.pdf

United Nations (UN), 2020. Development programme. Goal 2: zero hunger. UN, New York, NY, USA. Available at: https://www.undp. org/sustainable-development-goals\#zero-hunger

United Nations (UN), 2021. World Food Programme: Madagascar country brief: June 2021. UN, New York, NY, USA. Available at: https://www.wfp.org/countries/madagascar

Van Huis, A., 2013. Potential of insects as food and feed in assuring food security. Annual Review of Entomology 58: 563-583. https:// doi.org/10.1146/annurev-ento-120811-153704

Van Huis, A., Van Itterbeeck, J., Klunder, H., Mertens, E., Halloran, A., Muir, G. and Vantomme, P., 2013. Edible insects: future prospects for food and feed security. FAO, Rome, Italy, $187 \mathrm{pp}$.

Van Itterbeeck, J., Rakotomalala Andrianavalona, I.N., Rajemison, F.I., Rakotondrasoa, J.F., Ralantoarinaivo, V.R., Hugel, S. and Fisher, B.L., 2019. Diversity and use of edible grasshoppers, locusts, crickets, and katydids (Orthoptera) in Madagascar. Foods 8: 666. https:// doi.org/10.3390/foods8120666

World Bank, 2019. GDP per capita (current US\$) - Kenya. World Bank, Washington, DC, USA. Available at: https://data.worldbank. org/indicator/NY.GDP.PCAP.CD?locations $=$ KE

Yen, A.L., 2010. Edible insects and other invertebrates in Australia: future prospects. In: Durst, P.B. (ed.) Forest insects as food: humans bite back. Proceedings of a workshop on Asia-Pacific resources and their potential for development. 19-21 February 2008. Chiang Mai, Thailand. 